Saudi Journal of Medicine

Abbreviated Key Title: Saudi J Med ISSN 2518-3389 (Print) |ISSN 2518-3397 (Online) Scholars Middle East Publishers, Dubai, United Arab Emirates Journal homepage: https://saudijournals.com/sjm

Review Article

\title{
Dressings in Oral and Maxillofacial Region- A Review
}

Dr. Bhavan Chand Yemineni ${ }^{1 *}$, Dr. G. Jeevan Kumar ${ }^{2}$, Dr. Suraj Potdar ${ }^{3}$, Dr. Dani Mihir Tusharbhai ${ }^{4}$, Dr. Arundhati Pramod Hinge ${ }^{5}$, Dr. Makrand Sapat, MDS $^{6}$, Dr. Rahul Vinay Chandra Tiwari ${ }^{7}$

${ }^{1}$ Associate Professor, Dept of Dental and Oral Surgery, ASRAM Medical College, Eluru, Andhra Pradesh, India

${ }^{2}$ Consultant Oral and Maxillofacial Surgeon, Tirupati, Andhra Pradesh, India

${ }^{3}$ Senior lecturer, Department of Orthodontics and Dentofacial Orthopedics, Vasantdada Patil Dental College and Hospital, Sangli - Tasgaon Rd, Kavalapur, Maharashtra, India

${ }^{4}$ rd Year Postgraduate, Manipal College Of Dental Sciences, Manipal Academy Of Higher Education, Mangalore, India

${ }^{5}$ Dental Surgeon, Mahalaxmi Dental Clinic, Nerul, Navi Mumbai, India

${ }^{6}$ Consultant Prosthodontist, Ravi Nagar Wani, Yavatmal, Maharashtra, India

${ }^{7}$ FOGS, MDS, Consultant Oral \& Maxillofacial Surgeon, CLOVE Dental \& OMNI Hospitals, Visakhapatnam, Andhra Pradesh, India

DOI: $10.36348 / \operatorname{sim} .2020 . v 05 i 01.008$

| Received: 04.01.2020 | Accepted: 17.01.2020 | Published: 27.01.2020

*Corresponding author: Dr. Bhavan Chand Yemineni

\section{Abstract}

Oral and Maxillofacial region encompasses a wide spectrum of diseases, injuries and defects involving the head, neck, face, jaws and the hard and soft tissues of the oral cavity. Soft tissue injuries, when they occur in isolation or in combination with other injuries, are among the most challenging tasks to manage by the operator. In spite of their high incidence, there are very few studies noted in the literature which systematically elaborates the management of these injuries. This articles aims at emphasizing on the various dressings that can be used in the management of soft tissue injuries of the Oral and Maxillofacial region.

Keywords: oral cavity, Soft tissue injuries, Maxillofacial region.

Copyright @ 2020: This is an open-access article distributed under the terms of the Creative Commons Attribution license which permits unrestricted use, distribution, and reproduction in any medium for non-commercial use (NonCommercial, or CC-BY-NC) provided the original author and source are credited.

\section{INTRODUCTION}

Any break in the continuity of tissues covering the body which is usually associated with a defect is known as a wound [1]. The management of any wound is aimed at restoring the function and aesthetics in the shortest possible period of time [2]. The types of softtissue injuries encountered include abrasions, tattoos, simple or complex contused lacerations with loss of tissue, avulsions, bites and burns [3].

The extent of facial soft tissue injuries is governed by the impact force and type of injury into minor superficial wounds to massive avulsions. ${ }^{1}$ Disfigurement following trauma, is a social stigma and has the gross detrimental effect on the social well being of the patient [2]. An ideal dressing plays a vital role in establishing this goal of restoring the function and aesthetics in the shortest possible period of time.

A wide range of dressing materials are available that can be used in various clinical scenarios.
However, there isn't an ideal dressing material that can be used in all kinds of clinical scenarios that can deliver the same efficient result. Since there is little emphasized in the literature on type of dressing materials that can be used in the management of soft tissue injuries we have attempted to highlight the same in this article.

\section{Dressings}

A dressing may provide wound coverage; support and pressure to an area in order to prevent hematoma formation or temporary support to facial fractures. It is generally recommended to have freshly sutured wounds covered for the first 24-48 hours. Dressing materials have been advocated and applied to wounds in the mouth in order to reduce postoperative pain, promote healing and prevent infection [4, 5]. Some surgical materials have anticoagulant effects and are useful in achieving hemostasis, when bleeding is not otherwise controlled [6]. The various types of dressing materials are classified as shown in Table-1. 
Table-1

\begin{tabular}{|l|l|l|}
\hline S. No & Type of dressing material & Examples \\
\hline 1. & Basic dressing material & Gauze \\
& & Gamgee \\
& & Bandages \\
& & Elastic tapes \\
\hline 2. & Specialized dressing material & Vaseline gauze \\
& & Famycetin medicated gauze. \\
\hline 3. & Silastic gauze & Porous autoclavable material \\
\hline
\end{tabular}

\section{Topical Oral Dressing Materials Oxidized Regenerated Cellulose}

It is a hemostatic agent that chemically reacts with blood [6]. It is biocompatible, does not interfere with the wound healing and dissolves in 45 days $[6,7]$. It is extensively used in the field of neurosurgery. Few studies raised concerns over the use of oxidized regenerated cellulose claiming that it has potential neurotoxic effects [8].

\section{Whitehead's Varnish}

It aids in the prevention of capillary oozing and control of postoperative pain. It ensures that the soft tissue / bony cavities are free not infected in the postoperative period. In the maxillofacial region, it can be used as a dressing for skin graft donor sites, as a pack for cystic cavities of the jaw, to reduce pain following wisdom tooth removal, in orbital floor reconstruction, in cleft palate surgery, and with the surgical management of osteomyelitis [9-11].

\section{Carnoy's Solution}

It is a tissue fixative used primarily advocated prior to the enucleation of keratocystic odontogenic tumours [12]. Animal studies have demonstrated that an application for 3 minutes can cause reduction in nerve function while an application for five-minute can cause complete nerve impairment [13]

\section{Bismuth Iodoform Paraffin Paste}

It is used as a dressing material for fractures and open wounds with good success [14]. It is also advocated for dry socket and in prevention of epistaxis [15].

\section{Zinc Oxide-Based Dressings}

Eugenol has an anaesthetic properties and it is a known fact that its derivatives have been used for general anaesthesia [16]. These properties are generally required in the presence of inflammation to reduce postoperative pain. Non-eugenol zinc oxide-based materials avoid the potential for eugenol related cytotoxicity and allergy [6]. All of the zinc oxide materials act simply as a physical barrier to protect the wound and are not antibacterial.

\section{Antiseptic Solutions}

It is a well-known fact that irrigation of the wound is essential to remove contaminants which aid in reducing the infection rates. Normal saline is the most commonly used irrigation solution since it is an isotonic solution and does not interfere with the normal healing process [17]. Few recent studies have shown that ordinary tap water which is used for drinking is effective at irrigating and cleansing wounds as normal saline. ${ }^{1}$ Antiseptic solutions like cetrimide and chlorhexidine claim to destroy bacteria and have a deterrent effect on wounds provided that are in contact for atleast 20 minutes [1]. Povidine iodoine is not recommended for routine cleansing due to its cytotoxic effects on acute and healing wounds. Hydrogen peroxide, was earlier used to decontaminate and deslough the wound, but these properties are greatly reduced once the solution comes in contact with blood and pus. In addition to this, the thermal effect of the solution adversely affects the healthy tissues.

\section{Dressings}

The selection of a type of dressing for a wound is determined by a numerous factors in the form of anatomical location of the wound, type of wound, the presence or risk of infection and the duration of the wound [18]

Since superficial wounds produce little exudate a hydrocolloid or semipermeable film dressing are generally used whereas a low adherent dressings are particularly useful for the management of abrasions [1]. Dressings with the aid of paraffin gauze either plain or with medication and hydrocolloid dressings enhance the healing rates in partial thickness wounds such as burns, donor sites, superficial traumatic injuries and in few surgical wounds. They also reduce the pain and enhance the quality of life [19].

Literature also shows that bovine amniotic membrane can be used as a dressing for facial abrasions. They shorten the epithelization period and reduce the pain and enhance the quality of life [20]. Studies have been conducted in which human amniotic membrane was used with patients with necrotizing cervical fasciitis [21]. Ease of availability and available economically are the advantages of amniotic membrane in addition aiding in a better and faster healing of the wound with minimal scar formation. Studies have also shown that human amniotic membrane can be effectively used in deep dermal abrasive defects. 
In order to prevent drying and desiccation of exposed wound surfaces, it is advocated that abrasions should be covered with a thin layer of antibiotic ointment and dressed with cotton gauze or covered with an antibiotic coated cellulose acetate gauze [1]. thorough literature review reveals that there isn't any single dressing that is suitable for the management of all kinds of wounds. However, a few are appropriate for the management of a single wound during all stages of the healing cycle. Successful wound management depends on a flexible, knowledgeable approach to selection of a suitable dressing [18].

\section{CONCLUSION}

Reconstructive surgeons commonly encounter posttraumatic craniofacial soft tissue injuries in their routine medical practice. Key elements such as time of presentation in relation to injury, degree of injury, and anatomy involved play critical roles in determining the optimal method of management and whether management can be performed in the emergency room or the operating room. The relative lack of clinical literature regarding soft tissue trauma management has led to clinicians relying more on their personal experience.

\section{REFERENCES}

1. Mohan, M. C., Thilak, G. P., Shetty, P., Rai, A. J., \& Gohil, S. M. (2016). Management of abrasions in oral and maxillofacial surgery-a review. Nitte University Journal of Health Science, 6(3), 41-44.

2. Bhattacharya, V. (2012). Management of soft tissue wounds of the face. Indian journal of plastic surgery: official publication of the Association of Plastic Surgeons of India, 45(3), 436-443.

3. Ugboko, V. I., Olasoji, H. O., Ajike, S. O., Amole, A. O. D., \& Ogundipe, O. T. (2002). Facial injuries caused by animals in northern Nigeria. British Journal of Oral and Maxillofacial Surgery, 40(5), 433-437.

4. Jorkjend, L., \& Skoglund, L. A. (1990). Effect of non-eugenol-and eugenol-containing periodontal dressings on the incidence and severity of pain after periodontal soft tissue surgery. Journal of clinical periodontology, 17(6), 341-344.

5. Iramaneerat, S., Cunningham, S. J., \& Horrocks, E. N. (1998). The effect of two alternative methods of canine exposure upon subsequent duration of orthodontic treatment. International journal of paediatric dentistry, 8(2), 123-129.

6. Freedman, M., \& Stassen, L. F. (2013). Commonly used topical oral wound dressing materials in dental and surgical practice-a literature review. Journal Irish Dent Assoc. 59(4):190-195.

7. Alpaslan, C., Alpaslan, G. H., \& Oygur, T. (1997). Tissue reaction to three subcutaneously implanted local hemostatic agents. British Journal of Oral and Maxillofacial Surgery, 35(2), 129-132.
8. Loescher, A. R., \& Robinson, P. P. (1998). The effect of surgical medicaments on peripheral nerve function. British Journal of Oral and Maxillofacial Surgery, 36(5), 327-332.

9. Davies, H. T., \& Carr, R. J. (1990). Osteomyelitis of the mandible: a complication of routine dental extractions in alcoholics. British Journal of Oral and Maxillofacial Surgery, 28(3), 185-188.

10. Eyre, J., \& Zakrzewska, J. M. (1985). The conservative management of large odontogenic keratocysts. British Journal of Oral and Maxillofacial Surgery, 23(3), 195-203.

11. Rowe-Jones, J. M., Adam, E. J., \& Moore-Gillon, V. (1993). Subtle diagnostic markers of orbital floor blow-out fracture on coronal CT scan. The Journal of Laryngology \& Otology, 107(2), 161162.

12. Voorsmit, R. A. (1985). The incredible keratocyst: a new approach to treatment. Deutsche Zahnarztliche Zeitschrift, 40(6), 641-644.

13. Frerich, B., Cornelius, C. P., \& Wiethölter, H. (1994). Critical time of exposure of the rabbit inferior alveolar nerve to Carnoy's solution. Journal of oral and maxillofacial surgery, 52(6), 599-606.

14. Diggle, F. H. (1919). The Value of "BIPP" in Primary Operations for Gunshot Wounds of Joints. British medical journal, 1(3045), 572-573.

15. Garth, R. J. N., \& Brightwell, A. P. (1994). A comparison of packing materials used in nasal surgery. The Journal of Laryngology \& Otology, 108(7), 564-566.

16. Right, D. A., \& Payne, J. P. (1962). A clinical study of intravenous anaesthesia with a eugenol derivative, G. 29.505. BJA: British Journal of Anaesthesia, 34(6), 379-385.

17. Hollander, J. E., Richman, P. B., Werblud, M., Miller, T., Huggler, J., \& Singer, A. J. (1998). Irrigation in facial and scalp lacerations: does it alter outcome?.Annals of emergency medicine, 31(1), 73-77.

18. Thomas, S. (2008). Hydrocolloid dressings in the management of acute wounds: a review of the literature. International wound journal, 5(5), 602613.

19. Breivik, H., Borchgrevink, P. C., Allen, S. M., Rosseland, L. A., Romundstad, L., Breivik Hals, E. K., ... \& Stubhaug, A. (2008). Assessment of pain. BJA: British Journal of Anaesthesia, 101(1), 17-24.

20. Atiyeh, B. S., Dibo, S. A., \& Hayek, S. N. (2009). Wound cleansing, topical antiseptics and wound healing. International wound journal,6(6), 420430 .

21. Nanda, S., Chakraborty, S., \& Amit Ray, I. (2011). Healing of cervical necrotizing fasciitis using amniotic membrane as a dressing material. National journal of maxillofacial surgery, 2(2), 147-151. 